\title{
Silvicultural Implications in Hibrid of Eucalyptus urophylla S.T. Blake $\times$ Eucalyptus grandis Hill ex Maiden Stand
}

\author{
Claudiney do Couto Guimarães ${ }^{1}$, Dione Richer Momolli ${ }^{1}$, Mauro Valdir Schumacher ${ }^{1}$, \\ Aline Aparecida Ludvichak ${ }^{1}$, Huan Pablo de Souza ${ }^{2}$, José Mateus Wisniewski Gonsalves ${ }^{2}$ \\ \& Angélica Costa Malheiros ${ }^{1}$ \\ ${ }^{1}$ Department of Forest Science, Santa Maria Federal University, Santa Maria, Brazil \\ ${ }^{2}$ Futuragene Brasil Tecnologia, Itapetininga, São Paulo, Brazil \\ Correspondence: Dione Richer Momolli, Department of Forest Science, Santa Maria Federal University, Santa \\ Maria, Brazil. Tel: 55-559-9727-1859. E-mail: dionemomolli@gmail.com
}

Received: May 12, 2019

Accepted: June 25, 2019

Online Published: August 31, 2019

doi:10.5539/jas.v11n14p273

URL: https://doi.org/10.5539/jas.v11n14p273

\begin{abstract}
The objective of this work was to evaluate the silvicultural implications in a Eucalyptus urophylla S.T. Blake $\times$ Eucalyptus grandis Hill ex Maiden (Eucalyptus urograndis) stand 4.5 years-old, located in Alegrete - RS. The trees were fractionated in the following components: root, wood, bark, branches and leaves for later estimation of nutrient content and stock. An inventory was made for the dendrometric characterization of the stand. The nutrient concentration and stock in each component were evaluated. The nutrient removal was estimated considering three biomass harvesting scenarios: wood with bark + canopy, wood with bark and wood only. The nutritional balance and the number of rotations ( 4.5 years) of production were determined, considering the nutrient stock in the soil, the inputs through precipitation + mineral fertilization and the outputs from the biomass harvest. The risk of yield limitation among the nutrients considering the harvest of biomass showed the following pattern: Wood with bark + canopy: Sulfur $\sim$ Potassium $>$ Nitrogen $>$ Calcium $>$ Magnesium; Wood with bark: Sulfur $>$ Potassium $>$ Calcium $>$ Nitrogen $>$ Magnesium; Wood: Sulfur $>$ Potassium $>$ Nitrogen $>$ Magnesium $>$ Calcium. Phosphorus showed a tendency of nutritional sustainability in the three harvest scenarios evaluated.
\end{abstract}

Keywords: nutritional management, forest soils, sustainability, harvest

\section{Introduction}

Forestry with exotic species is present in most Brazilian biomes. The genus Eucalyptus occurs mainly in the Cerrado biome, in the southeastern and central-western regions of the country. In the Pampa biome, southwestern Rio Grande do Sul, commercial plantations for industrial purposes started to receive the largest investments since 2000, with wood production projects to serve the pulp, energy and sawn wood segments.

The Eucalyptus urophylla S.T. Blake $\times$ Eucalyptus grandis Hill ex Maiden (Eucalyptus urograndis) is characterized by good growth due to Eucalyptus grandis having a significant increase in the basic density of wood (better cellulose yield) and Eucalyptus uropohylla providing greater resistance to water deficit as well as adaptation to different forest sites, with consequent increase in yield indexes (Montanari et al., 2007).

Because eucalyptus is a fast-growing species, and consequently with high biomass production and nutrient accumulation, there are many questions about the impacts and sustainability of the stand. In this context, the study of the species' behavior in the edaphic environment and its other interactions provides elements that may contribute to increase yield gains in consonance with the use of natural resources, besides assisting in the decision making of the forester regarding the choice of the species to be implanted and the nutritional replacement for the next production cycle (Viera, Schumacher \& Caldeira, 2015).

The nutritional replacement for the long-term productive capacity of a forest site can be optimized when the use of biomass and nutrient losses by soil erosion are efficiently understood, and for this reason it is essential to quantify the biomass produced and the amount of nutrients exported by the forest harvest (Schumacher \& Caldeira, 2001; Schumacher et al., 2011). Moreover, removal of one or more components of the tree through 
high-intense harvest (e.g., wood with bark) increases the cost with corrective fertilization and maintenance (Viera et al., 2013).

The objective of this study was to evaluate the implications of silvicultural management in a Eucalyptus urograndis stand established in the Pampa biome, by estimating: biomass and nutrients in tree components (leaves, branches, bark, wood and root), nutrient removal under different harvesting scenarios and nutritional balance.

\section{Material and methods}

\subsection{Characterization of the Experimental Area}

The experiment was carried out in a 4.5 year-old commercial stand, implanted with clonal Eucalyptus urograndis seedlings at a spacing of $3.5 \mathrm{~m} \times 2.5 \mathrm{~m}$, located at Fazenda Cabanha da Prata, in the municipality of

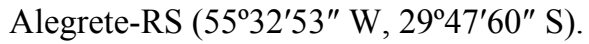

The region climate according to Köppen's classification (Alvares et al., 2014) is considered humid sub-temperate with frosts from May to August, and intense heat mainly in the months of January and February, with average temperature of the warmest month $>22{ }^{\circ} \mathrm{C}$ and average annual temperature $>18{ }^{\circ} \mathrm{C}$. Precipitation has rainfall ranging from 1250 to $1500 \mathrm{~mm}$.

The soil is classified as typical Distrophic Red Argisol (EMBRAPA, 2006). According to Pessotti (2006), this class involves deep soils, well drained, sand texture on the surface, followed by sandy clay loam texture in the deepest horizons. Chemically they are soils with medium to high values of exchangeable bases, subject to leaching of mobile nutrients such as $\mathrm{N}$ and $\mathrm{K}$, and presents moderate retrogradation of soluble Phosphorus. According to Streck et al. (2008) the soil presents low natural fertility. The physical and chemical attributes verified in the soil analysis of the sample units are presented in Table 1.

Table 1. Physical and chemical properties of the soil in the area implanted with 4.5 year-old Eucalyptus urograndis in the Pampa Biome

\begin{tabular}{|c|c|c|c|c|c|c|c|c|c|}
\hline \multirow{2}{*}{ Depth } & \multirow{2}{*}{ Density } & \multicolumn{4}{|c|}{ Distribution of particles $\%$} & \multirow{2}{*}{$\mathrm{OM}$} & \multirow{2}{*}{$\mathrm{pH}$} & \multirow{2}{*}{$\mathrm{CTC}_{\text {efet. }}$} & \multirow{2}{*}{$\mathrm{Ca}$} \\
\hline & & Coarse sand & Fine sand & Silte & Clay & & & & \\
\hline $\mathrm{cm}$ & $\mathrm{g} \mathrm{cm}^{-3}$ & & & & & $\%$ & $\left(\mathrm{H}_{2} \mathrm{O}\right)$ & \multicolumn{2}{|c|}{---- $\mathrm{cmol}_{\mathrm{c}} \mathrm{dm}^{-3}$---- } \\
\hline $0-20$ & 1.5 & 29.0 & 11.0 & 37.0 & 24.0 & 1.8 & 4.3 & 4.3 & 1.0 \\
\hline $20-40$ & 1.5 & 24.0 & 11.0 & 35.0 & 29.0 & 1.4 & 4.5 & 4.7 & 1.1 \\
\hline $40-100$ & 1.3 & 19.0 & 11.0 & 32.0 & 38.0 & 1.3 & 4.6 & 5.4 & 1.5 \\
\hline Depth & $\mathrm{Mg}$ & $\mathrm{P}$ & $\mathrm{K}$ & $\mathrm{S}$ & $\mathrm{B}$ & $\mathrm{Cu}$ & $\mathrm{Zn}$ & $\mathrm{V}$ & $\mathrm{m}$ \\
\hline $\mathrm{cm}$ & $\mathrm{cmol}_{\mathrm{c}} \mathrm{dm}^{-3}$ & \multicolumn{6}{|c|}{ 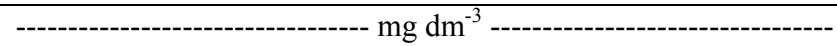 } & \multicolumn{2}{|c|}{---------- \% --------- } \\
\hline $0-20$ & 0.6 & 9.1 & 44.0 & 8.0 & 0.6 & 1.3 & 1.2 & 8.6 & 60.0 \\
\hline $20-40$ & 0.7 & 2.2 & 17.3 & 5.5 & 0.3 & 1.3 & 0.6 & 8.8 & 60.0 \\
\hline $40-100$ & 0.9 & 0.9 & 12.3 & 5.9 & 0.3 & 1.2 & 0.2 & 11.0 & 54.0 \\
\hline
\end{tabular}

Note. $\mathrm{OM}=$ Organic matter; $\mathrm{V}=$ Base saturation; $\mathrm{m}=$ Aluminium saturation.

Planting was carried out with initial density of 1150 plants per hectare. For the implantation, cultural treatments were: subsoiling in September of 2007, using subsoiler with three stems, fertilization by incorporation of $300 \mathrm{~kg}$ $\mathrm{ha}^{-1}$ of reactive natural phosphate (GAFSA, $12 \% \mathrm{P}_{2} \mathrm{O}_{5}$ soluble in citric acid) in the center of the planting line and $40 \mathrm{~cm}$ deep, followed by harrowing.

The first fertilization was carried out 15 days after planting, using the formula $\mathrm{N}-\mathrm{P}_{2} \mathrm{O}_{5}-\mathrm{K}_{2} \mathrm{O}$ of $06-30-06+0.6 \%$ $\mathrm{B}$ (Boron), $110 \mathrm{~g} \mathrm{plant}^{-1}\left(126.5 \mathrm{~kg} \mathrm{ha}^{-1}\right)$ divided in two sub-doses of $55 \mathrm{~g}$ incorporated at $15 \mathrm{~cm}$ of each side of the plant. The second fertilization was performed at 90 days post-planting, using the formula $20-05-20+0.2 \% \mathrm{~B}$ (Boron) $+0.4 \% \mathrm{Zn}$ (Zinc), $122 \mathrm{~g}$ plant $^{-1}\left(140 \mathrm{~kg} \mathrm{ha}^{-1}\right)$ applied manually in the canopy projection. The third fertilization was performed at 270 days, using the formula 22-00-18 $+1 \% \mathrm{~S}$ (Sulfur) $+0.3 \% \mathrm{~B}$ (Boron), $122 \mathrm{~g}$ plant $^{-1}\left(140 \mathrm{~kg} \mathrm{ha}^{-1}\right)$ applied mechanically between lines.

\subsection{Estimation of Biomass and Nutrient Stock}

The methodology used to estimate the biomass and the nutrients was adapted from Melo et al. (1995) and Neves (2000). In March 2011, when the plantation was 4.5 years old, three sample plots of $10 \mathrm{~m} \times 35 \mathrm{~m}\left(350 \mathrm{~m}^{2}\right)$ were randomly distributed in an area of 10 hectares, where the diameter was measured at breast height (DBH) and the 
height of $20 \%$ of the trees, for the dendrometric characterization of the stand. There was a mean DBH of $17.6 \mathrm{~cm}$ and a total height of $22.7 \mathrm{~m}$. The average annual increment with bark (AAI b) observed was $47.2 \mathrm{~m}^{3} \mathrm{ha}^{-1}$, with a density of 1110 plants ha ${ }^{-1}$.

After DBH measurement, 3 trees were selected per sample by the mean DBH-standard deviation, mean DBH and mean $\mathrm{DBH}+$ standard deviation, totaling 9 trees. The selected trees were sectioned at soil level and the volume with and without bark determined through rigorous sampling according to the methodology described by Smalian (Péllico Netto \& Brena, 1997), and later fractionated in the following components: leaf, branch, bark, wood and root. The total wet biomass of each component was determined directly in the field by weighing with hook scale.

For dry biomass estimation, wet samples $(150 \mathrm{~g}$ each) of the different components were collected, one sample per tree (randomly) of leaf and branch components. Three samples of wood and bark (150 g to $500 \mathrm{~g}$ ) were collected per tree, distributed along the commercial stand. Samples were obtained at the median positions of the sections resulting from the division into three equal parts of the trunk. The minimum diameter considered was 8 $\mathrm{cm}$.

For the biomass of the roots, 3 trees (one in each plot) were selected among the 9 used for the biomass above the soil, being chosen by the mean DBH. The root system (stump and thick roots) of the trees was extracted by backhoe and manual excavation (shovels and hoes) in the useful area, considering the spacing between the trees of $3.5 \mathrm{~m} \times 2.5 \mathrm{~m}\left(8.75 \mathrm{~m}^{2}\right)$ and a depth of $1 \mathrm{~m}$. The roots were weighed in their entirety and a sample $(150 \mathrm{~g})$ was collected. After weighing the samples were stored in paper bags and sent to the Forest Ecology Laboratory of the Forest Engineering Department/UFSM. The samples were dried in forced air oven at $70{ }^{\circ} \mathrm{C}$, and weighed in a $0.01 \mathrm{~g}$ precision scale after reaching constant weight.

For the chemical analysis and estimation of total nutrient stocks in the soil, samples were collected in the pits where the roots were excavated, in the layers of 0-20, 20-40 and 40-100 cm. During soil sampling for chemical analyzes, samples were also collected at the mid-points of the layers, using Kopecky volumetric rings to determine soil density. The analyzes of plant tissues and soil were followed by the methodology of Tedesco et al. (1995), recommended by the SBCS-CQFS (2016) and Miyazawa (1999).

Total tree biomass $\mathrm{ha}^{-1}$ was estimated by multiplying the sampled dry mass average of the sampled trees by the total number of individuals in each plot, extrapolating to the plots area, determining the accumulated biomass therein. The same extrapolation procedure was used to determine the accumulated biomass $\mathrm{ha}^{-1}$.

The amount of each nutrient in the different components was obtained by multiplying nutrient concentration and dry biomass. Total amount of nutrients hectare ${ }^{-1}$ was estimated by extrapolation of the amounts observed in each plot, similar to the procedure described above. Total nutrient stocks in the soil were estimated bymultiplying soil volume, nutrient concentration and soil density obtained at the midpoint of each layer. For Nitrogen, due to its great dynamics in the soil, and because it is contained in little available forms (very stable humic fractions), only $10 \%$ was considered as available to the plants.

\subsection{Estimation of Nutritional Balance and Number of Production Rotations (NPR)}

The nutrient balance estimation was obtained by the difference between nutrient input via mineral fertilization + available stocks in the soil (Table 2) and the output, as a result of the nutrient removal through the biomass harvest, considering three scenarios: 1) Wood with bark + canopy, 2) Wood with bark, and 3) Wood, with the use of the whole trunk, without discarding the tree tops.

Table 2. Annual intake by fertilization and available stock in the soil of macronutrients in 4.5 years-old Eucalyptus urograndis plantation in the Pampa Biome

\begin{tabular}{lllllll}
\hline Input & $\mathrm{N}$ & $\mathrm{P}$ & $\mathrm{K}$ & $\mathrm{Ca}$ & $\mathrm{Mg}$ & $\mathrm{S}$ \\
\hline & $--1 \mathrm{yg}^{-1}$ & \\
Mineral Fertilization & 67.0 & 81.0 & 61.0 & - & - & 1.0 \\
Stock available in the soil & 1003.2 & 35.9 & 215.3 & 2101 & 741.1 & 55.7 \\
\hline
\end{tabular}




\subsection{Statistical Analyzes}

The contrast of the means was assessed using the SAS package (2003) through Tukey's test $(\mathrm{P}>0.05)$. A completely randomized design of the sample plots was considered, where each tree corresponded to a replicate for its respective components of biomass and nutrients.

\section{Results and Discussion}

\subsection{Biomass and Nutrients}

The biomass production was $158.1 \mathrm{Mg} \mathrm{ha}^{-1}$, following the compartment order (Figure 1): Wood $(70 \%)>$ root $(15 \%)>$ branch $(7 \%)>$ bark, $(6 \%)>$ leaf $(2 \%)$.

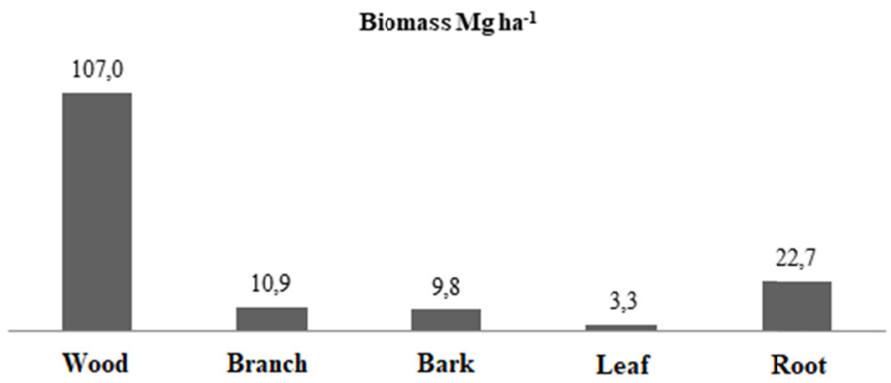

Figure 1. Production of biomass of the different components in a hybrid of Eucalyptus urophylla $\times$ Eucalyptus grandis stand

Biomass production varies according to the availability of forest site resources, influencing carbon compartmentalization (Ryan et al., 2010). The genetic, the edaphoclimatic region and the management factors are directly related to the production capacity of the species. Barros and Comerford (2002) explain that the largevariability of the eucalyptus plantations productivity in different regions is mainly associated to the different type of soil besides the total nutrient amount available within.

By the biomass quantification of two different Eucalyptus spp. genotypes. at 4.5 years of age, Guimarães et al. (2019a) found a total production of 137 for Eucalyptus grandis and $122 \mathrm{Mg} \mathrm{ha}^{-1}$ for E. dunnii Maiden. The wood component accounted for 65 and $63 \%$, respectively. These results point to the genetic material as being important indicative of productivity.

Regarding the relative above-ground biomass partition, similar results were found by Poggianiand Schumacher (1993) and Pereira et al. (1984) for 8 and 9 years of age Eucalyptus saligna Smith, respectively, with $85 \%$ of the above-ground biomass located in the wood components. Spangenberg et al. (1996) verified that Eucalyptus urograndis individuals, at 4.5 years of age, $90 \%$ of the biomass is distributed in the same components. For individuals of Eucalyptus globulus Labill at 10 years of age, and Eucalyptus saligna at 4 years of age, Vieira (2012) and Beulch (2013) observed that wood + bark components accounted for $94 \%$ and $86 \%$ of above-ground biomass, respectively.

Carvalho et al. (2019) in a 4.5 years-old Eucalyptus urograndis in the same region showed that $81.3 \%$ refer to the percentage of wood + bark. Quantifying the biomass in 7-year-old Eucalyptus benthamii Maiden, Guimarães et al. (2019b) found that $87.7 \%$ of the biomass was found in wood + bark. Work developed by Momolli et al. (2019) in a 10-year-old Eucalyptus saligna stands in southern Brazil shows that $95 \%$ of the biomass was of wood + bark. Given this, it is evident that besides the forest site, the maturity of the stand also influences the amount of biomass in the different compartments.

Schumacher (1998) with Eucalyptus globulus, at 4 years of age observed that the canopy represents $28 \%$ of the total biomass above the ground, while the remaining $72 \%$ are represented by wood + bark. The same author found the same trend of distribution in a study with Eucalyptus saligna, at 4 and 7 years of age, which was also observed by Caldeira (1998) with Acacia mearnsii De Wild., at 2 years and 4 months of age. Turner and Lambert (2008), in a study with Eucalyptus grandis and Eucalyptus pilularis Smith, at 5 years of age, verified that for the biomass above the soil, 70 and $73 \%$, repectively was represented by the biomass of wood + bark.

Table 3 shows the concentration of nutrients in the different biomass components. It was observed that there is a statistically significant difference $(p<0.05)$ between components. 
Table 3. Mean concentration nutrients by biomass components in 4.5-year-old Eucalyptus urograndis standin the Pampa Biome

\begin{tabular}{|c|c|c|c|c|c|c|c|c|c|c|c|}
\hline \multirow{2}{*}{ Component } & \multicolumn{6}{|c|}{ Macronutrients $\left(\mathrm{g} \mathrm{kg}^{-1}\right)$} & \multicolumn{5}{|c|}{ Micronutrients $\left(\mathrm{mg} \mathrm{kg}^{-1}\right)$} \\
\hline & $\mathrm{N}$ & $\mathrm{P}$ & $\mathrm{K}$ & $\mathrm{Ca}$ & $\mathrm{Mg}$ & $\mathrm{S}$ & $\mathrm{B}$ & $\mathrm{Cu}$ & $\mathrm{Fe}$ & $\mathrm{Mn}$ & $\mathrm{Zn}$ \\
\hline Wood & $1.1 \mathrm{c}$ & $0.1 \mathrm{~b}$ & $1.4 \mathrm{c}$ & $0.2 \mathrm{c}$ & $0.2 \mathrm{~d}$ & $0.4 \mathrm{~b}$ & $3.5 b$ & $3.3 \mathrm{a}$ & $17.6 \mathrm{~b}$ & $14.1 \mathrm{c}$ & $4.1 \mathrm{c}$ \\
\hline Bark & $4.7 \mathrm{~b}$ & $0.8 \mathrm{a}$ & $5.5 b$ & $20.8 \mathrm{a}$ & $3.6 \mathrm{a}$ & $0.5 b$ & $8.1 \mathrm{~b}$ & $4.7 \mathrm{a}$ & $34.1 \mathrm{~b}$ & $552.0 \mathrm{a}$ & $7.1 \mathrm{c}$ \\
\hline Leaf & $17.8 \mathrm{a}$ & $1.8 \mathrm{a}$ & $6.7 \mathrm{a}$ & $6.0 \mathrm{~b}$ & $2.8 \mathrm{~b}$ & $1.2 \mathrm{a}$ & $31.1 \mathrm{a}$ & $9.7 \mathrm{a}$ & $73.6 b$ & $402.7 \mathrm{~b}$ & $18.3 \mathrm{a}$ \\
\hline Branch & $2.9 b$ & $0.5 b$ & $1.7 \mathrm{c}$ & $6.7 \mathrm{~b}$ & $1.5 \mathrm{c}$ & $0.4 \mathrm{~b}$ & $4.4 \mathrm{~b}$ & $8.0 \mathrm{a}$ & $18.7 \mathrm{~b}$ & $247.2 b$ & $10.5 b c$ \\
\hline Root & $4.1 \mathrm{~b}$ & $0.3 b$ & $1.6 \mathrm{c}$ & $3.3 \mathrm{c}$ & $0.4 \mathrm{~d}$ & $0.6 b$ & $10.2 b$ & $4.0 \mathrm{a}$ & $386.5 \mathrm{a}$ & $32.7 \mathrm{c}$ & $13.1 \mathrm{ab}$ \\
\hline
\end{tabular}

Note. Vertical letters do not differ statistically between nutrient concentrations in the different biomass components, at the 0.05 level of significance by the Tukey test.

According to Pallardy (2008), the difference in nutrient concentration among plant components is related to maturity. The more mobile nutrients of senescent tissues tend to move to regions with higher metabolic activity. Poggiani and Schumacher (2004), explain biochemical cycling is more important for the maintenance of nutrients with high mobility $(\mathrm{N}, \mathrm{P}, \mathrm{K}$ and $\mathrm{Mg}$ ), and lower for low mobility nutrients (Ca, S) and also micronutrients.

Considering only the biomass above the soil, the leaves had the highest concentration for most of the elements. Viera (2012) notes that most nutrients tend to focus on newer plant structures, especially on leaves, where the main metabolic processes (transpiration and photosynthesis) occur. The high concentration of $\mathrm{Ca}$ in the bark is related to the low mobility of this element in the plant phloem and also to be a structural component of the cell membrane (Ferri, 1985).

Total storage of macro and micro-nutrients was $1232 \mathrm{~kg} \mathrm{ha}^{-1}$ and $14.7 \mathrm{~kg} \mathrm{ha}^{-1}$, respectively (Table 4). Relative nutrient allocation for above-ground biomass was of: $\mathrm{N}(25 \%), \mathrm{P}(2 \%), \mathrm{K}(25 \%), \mathrm{Ca}(34 \%), \mathrm{Mg}(8 \%), \mathrm{S}$ and $\mathrm{B}$ (5\%), $\mathrm{Cu}(4 \%), \mathrm{Mn}(86 \%)$, and $\mathrm{Zn}(5 \%)$. Allocation magnitude followed the order $\mathrm{Ca}>\mathrm{N} \sim \mathrm{K}>\mathrm{Mg}>\mathrm{S}>\mathrm{P}$, and $\mathrm{Mn}>\mathrm{B} \sim \mathrm{Zn} \mathrm{Cu}$ (Figure 1).

Table 4. Nutrient amounts by biomass components in a 4.5-year-old Eucalyptus urograndis standin the Pampa Biome

\begin{tabular}{|c|c|c|c|c|c|c|c|c|c|c|}
\hline \multirow{2}{*}{ Component } & \multicolumn{6}{|c|}{ Macronutrient } & \multicolumn{4}{|c|}{ Micronutrient } \\
\hline & $\mathrm{N}$ & $\mathrm{P}$ & $\mathrm{K}$ & $\mathrm{Ca}$ & $\mathrm{Mg}$ & $\mathrm{S}$ & $\mathrm{B}$ & $\mathrm{Cu}$ & $\mathrm{Mn}$ & $\mathrm{Zn}$ \\
\hline \multirow{3}{*}{ Wood } & \multicolumn{6}{|c|}{----------------------------- kg ha ${ }^{-1}$------------------------- } & \multicolumn{4}{|c|}{ 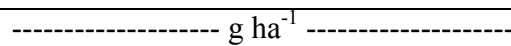 } \\
\hline & 118.4 & 6.4 & 150.9 & 26.2 & 20.7 & 39.2 & 379.9 & 365.5 & 1573.6 & 440.0 \\
\hline & $(34.1)$ & $(21.7)$ & $(53.0)$ & (6.4) & $(22.3)$ & $(58.8)$ & $(44.6)$ & $(58.3)$ & $(12.9)$ & $(44.1)$ \\
\hline$\sigma$ & 17.7 & 2.6 & 28.5 & 11.5 & 3.3 & 2.7 & 56.0 & 37.0 & 680.1 & 220.3 \\
\hline $\mathrm{CV}$ & 14.9 & 39.7 & 18.9 & 43.7 & 15.8 & 6.8 & 53.5 & 10.1 & 43.2 & 50.1 \\
\hline \multirow[t]{2}{*}{ Bark } & 46.9 & 7.7 & 54.7 & 212.1 & 36.2 & 4.9 & 84.3 & 47.2 & 5682.3 & 72.5 \\
\hline & (13.5) & $(26.1)$ & (19.2) & $(51.6)$ & (38.9) & (7.3) & (9.9) & (7.5) & $(46.5)$ & (7.3) \\
\hline$\sigma$ & 13.3 & 2.2 & 15.0 & 78.3 & 10.3 & 1.2 & 48.8 & 13.4 & 1419.6 & 24.4 \\
\hline $\mathrm{CV}$ & 28.3 & 29.0 & 27.5 & 36.9 & 28.3 & 24.3 & 57.9 & 28.4 & 25.0 & 33.7 \\
\hline \multirow[t]{2}{*}{ Leaf } & 54.0 & 4.2 & 22.9 & 20.2 & 9.4 & 4.1 & 102.0 & 33.0 & 1379.4 & 63.1 \\
\hline & (15.5) & (14.2) & $(8.0)$ & (4.9) & (10.1) & (6.1) & $(12.0)$ & (5.3) & (11.3) & $(6.3)$ \\
\hline$\sigma$ & 24.6 & 0.9 & 4.3 & 3.6 & 2.0 & 0.7 & 15.4 & 4.8 & 1419.6 & 19.1 \\
\hline $\mathrm{CV}$ & 45.6 & 21.0 & 18.8 & 17.6 & 21.7 & 18.1 & 15.1 & 14.6 & 25.0 & 30.3 \\
\hline \multirow[t]{2}{*}{ Branch } & 32.9 & 5.2 & 19.0 & 75.6 & 16.8 & 5.0 & 48.4 & 89.0 & 2822.3 & 118.6 \\
\hline & $(9.5)$ & (17.6) & (6.7) & (18.4) & $(18.1)$ & (7.5) & (5.7) & $(14.2)$ & $(23.1)$ & (11.9) \\
\hline$\sigma$ & 8.6 & 1.8 & 7.4 & 19.1 & 4.5 & 0.9 & 12.3 & 18.4 & 405.8 & 20.0 \\
\hline $\mathrm{CV}$ & 26.2 & 34.9 & 38.7 & 25.3 & 26.6 & 17.9 & 25.5 & 20.7 & 29.4 & 16.9 \\
\hline \multirow[t]{2}{*}{ Root } & 95.1 & 6.0 & 37.2 & 76.7 & 9.9 & 13.5 & 238.1 & 92.6 & 753.3 & 303.9 \\
\hline & (27.4) & (20.3) & (13.1) & (18.7) & (10.6) & $(20.2)$ & (27.9) & (14.8) & $(6.2)$ & $(30.4)$ \\
\hline$\sigma$ & 13.8 & 0.2 & 9.3 & 19.1 & 0.8 & 1.2 & 40.6 & 8.0 & 226.4 & 30.9 \\
\hline $\mathrm{CV}$ & 14.5 & 3.5 & 25.1 & 24.9 & 8.4 & 9.2 & 17.1 & 8.6 & 30.0 & 10.2 \\
\hline \multirow[t]{2}{*}{ Total } & 347.3 & 29.5 & 284.7 & 410.8 & 93.0 & 66.7 & 852.7 & 627.3 & 12210.9 & 998.1 \\
\hline & (100) & (100) & (100) & (100) & (100) & (100) & (100) & (100) & (100) & (100) \\
\hline
\end{tabular}

Note. Values in parentheses refer to the percentage contribution of each component in relation to the total of analyzed nutrient; $\sigma=$ Standard deviation; $\mathrm{CV}=$ coefficient of variation. 
Hernández et al. (2009), observed biomass production, concentration and nutrient amounts in the various components of eucalyptus trees are directly related to planting density and soil fertility. Poggiani and Schumacher (1993) emphasize the nutritional characteristics of the species and the age of harvest influence the accumulation of nutrients. The magnitude of concentration of the macronutrients presented the following order: leaf $>$ bark $>$ branch $>$ root $>$ wood. For micronutrients the order was the following: root $>$ leaf $>$ bark $>$ branch $>$ wood.

\subsection{Silvicultural Implications After Harvest}

Harvesting of all biomass above ground is the most aggressive scenario of nutrient removal, which is reflected in the nutritional balance and maintenance of the productive capacity of the site. It can be observed that the Phosporus presents nutritional sustainability trend in the three scenarios evaluated (Table 5).

Table 5. Nutritional balance and estimating the number of production rotations in 4.5-year-old-nutrient Eucalyptus urograndis stand in the Pampa Biome

\begin{tabular}{lllllll}
\hline \multirow{2}{*}{ Harvest simulation } & \multicolumn{7}{c}{ Macronutrients } \\
\cline { 2 - 6 } & $\mathrm{N}$ & $\mathrm{P}$ & $\mathrm{K}$ & $\mathrm{Ca}$ & $\mathrm{Mg}$ & $\mathrm{S}$ \\
\hline \multirow{2}{*}{ Wood with bark + tree tops } & $------------------------\mathrm{kg} \mathrm{ha}^{-1}-----------------------------$ \\
Balance & 252 & 24 & 248 & 334 & 83 & 53 \\
NRP & 843 & 96 & 66 & 1793 & 668 & 6 \\
Wood with bark & 8 & $\boldsymbol{i}$ & 3 & 8 & 11 & 2 \\
Balance & 165 & 14 & 206 & 238 & 57 & 44 \\
NRP & 930 & 106 & 108 & 1889 & 694 & 15 \\
Wood only & 17 & $\boldsymbol{i}$ & 4 & 11 & 18 & 3 \\
Balance & 118 & 6 & 151 & 26 & 21 & 39 \\
NRP & 977 & 114 & 163 & 2101 & 730 & 20 \\
\hline
\end{tabular}

Note. $\mathrm{NRP}=$ Number of Production Rotations, $i=$ infinite rotations, suggesting nutritional sustainability of $\mathrm{P}$ in the production system.

The removal of the wood provided the lowest removal of nutrients from the system because although the wood presents the highest production of biomass, the highest concentration of nutrients is located in the leave, branch, bark and roots compartments. According to the intensity of the biomass harvest, the following nutrient removal gradient can be defined: i) Wood + bark + tree tops: $\mathrm{Ca}>\mathrm{N}>\mathrm{K}>\mathrm{Mg}>\mathrm{S}>\mathrm{P}$; ii) Wood + bark: $\mathrm{Ca}>\mathrm{K}>\mathrm{N}>$ $\mathrm{Mg}>\mathrm{S}>\mathrm{P}$; iii) Wood only: $\mathrm{K}>\mathrm{N}>\mathrm{Mg}>\mathrm{Ca}>\mathrm{S}>\mathrm{P}$, and $\mathrm{Mn}>\mathrm{Fe}>\mathrm{B}>\mathrm{Zn}>\mathrm{Cu}$.

The greatest differences in nutrient permanence according to the harvest intensity were observed in $\mathrm{Ca}$ and $\mathrm{Mg}$, and it was observed these nutrients present in greater proportions in the bark component. According to Schumacher and Caldeira (2001), the harvesting of the wood with the bark enhances the nutrient removal from the forest site, especially for Ca. Considering the harvest of the wood with the bark and only the wood, similar results were found by Viera (2012) and Neves (2000), in studies with the hybrid of Eucalytpus urophylla $\times$ Eucalytpus globulus, Eucalyptus grandis, and Eucalyptus saligna. This trend of distribution was not found by Spangenberg et al. (1996) and Merino et al. (2005), studying Eucalytpus urograndis and Eucalytpus globulus, respectively.

Although there is a greater removal of the nutrients from the stands with the increase of the biomass harvest intensity, in practice, the absolute nutrient depletion does not occur. When analyzing this behavior, we observe a transition from a level of productivity in one cycle, to a lower level of productivity in the next cycle, and so on (Schumacher et al., 2013).

The most productive sites extract the highest amounts of nutrients and reach exhaustion more quickly. Therefore, the maintenance of high levels of productivity will depend on the use of fertilizers, harvesting only the wood component and conservation principles (Bizon, 2005). Therefore, in order to reestablish nutritional balance and ensure forest productivity in the next production cycles, large inputs of fertilizer capital (inputs, equipment and labor) should be used, which will directly increase the cost of the crop. 
The maintenance of crop residues on the soil will contribute to increase the organic matter contents, which are very low in this soil condition. Moreover, it plays animportant role in the soil protection/conservation and in the maintenance of nutrients suplly into the system, especially Potasium.

Considering that this study was carried out in a 4.5 -years-old stand population, it is assumed that in a 7 years-old stand the nutritional dynamics should change.

\section{Conclusions}

The biomass and nutrient stock research are important to guide forest management and forestry techniques, considering the different scenarios of the forest harvest.

In the wood, the highest biomass production and the highest nutrient stocks were observed, except for the Ca, $\mathrm{Mg}$ and $\mathrm{Mn}$ found in the bark. The wood harvesting resulted in into the best scenario for the nutritional sustainability of the site.

The number of production rotations suggests that the $\mathrm{P}$ demand can be supplied throughthe cover fertilization without the necessity of the natural phosphate in the subsoiling. The macronutrients $\mathrm{S}, \mathrm{K}$ and $\mathrm{Mg}$ were the elements that presented the greatest risk of limiting productivity according to nutritional balance.

\section{References}

Alvares, C. A., Stape, J. L., Sentelhas, P. C., Gonçalves, J. L. M., \& Sparovek, G. (2014). Köppen's climate classification map for Brazil. Meteorologische Zeitschrift, 22(6), 711-728. https://doi.org/10.1127/ 0941-2948/2013/0507

Barros, N. F., \& Comerford, N. B. (2002). Sustentabilidade da produção de florestas plantadas na região tropical. In V. V. H. Alvarez et al. (Eds.), Tópicos em ciência do solo (pp. 487-592). Viçosa, Sociedade Brasileira de Ciência do Solo, Viçosa, Folha de Viçosa.

Beulch, L. S. (2013). Biomassa e nutrientes em um povoamento de Eucalyptus saligna Smith submetido ao primeiro desbaste (Dissertação, Mestrado em Engenharia Florestal, Universidade Federal de Santa Maria, Santa Maria).

Bizon, J. M. C. (2006). Avaliação da sustentabilidade nutricional de plantios de Pinus taeda L. usando um balanço de entrada-saída de nutrients (Dissertação, Mestrado em Recursos Florestais, Escola Superior de Agricultura Luiz de Queiroz, Universidade de São Paulo, Piracicaba).

Caldeira, M. V. W. (1998). Quantificação da biomassa e do conteúdo de nutrientes em diferentes procedências de Acácia-negra Acacia mearnsii (Dissertação Mestrado em Engenharia Florestal, Universidade Federal de Santa Maria, Santa Maria).

Carvalho, R., Momolli, D., \& Schumacher, M. (2019). Selection of Models for Above-Ground Biomass in a Eucalyptus urograndis Stand. Journal of Experimental Agriculture International, 34(5), 1-9. https://doi.org/ 10.9734/jeai/2019/v34i530187

EMBRAPA (Empresa Brasileira de Pesquisa Agropecuária). (2006). Sistema Brasileiro de Classificação de Solos (p. 306). Rio de Janeiro.

Ferri, M. G. (1985). Fisiologia Vegetal (Vol. I \& II). Sao Paulo: EPU.

Guimarães, C., Momolli, D., Souza, H., Schumacher, M., Ludvichak, A., \& Malheiros, A. (2019b). Biomass Production and Nutritional Characterization of Eucalyptus benthamii in the Pampa Biome, Brazil. Journal of Experimental Agriculture International, 35(2), 1-9. https://doi.org/10.9734/jeai/2019/v35i230201

Guimarães, C., Schumacher, M., Momolli, D., Souza, H., Ludvichak, A., \& Malheiros, A. (2019a). Biomass Production and Nutritional Efficiency in Eucalyptus Genotypes in the Pampa Biome. Journal of Experimental Agriculture International, 34(6), 1-10. https://doi.org/10.9734/jeai/2019/v34i630189

Hernández, J. (2009). Nutrient export and harvest residue decomposition patterns of a Eucalyptus dunnii Maiden plantation in temperate climate of Uruguay. Forest Ecology and Management, 258(2), 92-99. https://doi.org/10.1016/j.foreco.2009.03.050

Melo, V. F. (1995). Balanço nutricional, eficiência de utilização e avaliação da fertilidade do solo em P, K, Ca e Mg em plantios de eucalipto no Rio Grande do Sul. IPEF, 48/49, 8-17.

Merino, A. (2005). Nutrient exports under different harvesting regimes in fast-growing forest plantations in southern Europe. Forest Ecology and Management, 207(3), 325-339. https://doi.org/10.1016/ j.foreco.2004.10.074 
Miyazawa, M., Pavan, M. A., \& Muraoka, T. (1999). Manual de análises químicas de solos, plantas e fertilizantes. Brasília: Embrapa Comunicação Para Transferência de Tecnologia.

Momolli, D., Schumacher, M., Ludvichak, A., \& Araújo, E. (2019). Modeling and Biomass Quantification in Eucalyptus saligna Smith Stand at the End Rotation in the South of Brazil. Journal of Experimental Agriculture International, 33(3), 1-10. https://doi.org/10.9734/jeai/2019/v33i330146

Montanari, R., Junior, J. M., Campos, M. C. C., Herbert, I., \& Cavalcante, L. (2007). Níveis de resíduos de metalurgia e substrato na formação de mudas de eucalipto (Eucalyptus urograndis). Revista de Biologia e Ciências da Terra, 7(1), 59-66.

Neves, J. C. L. (2000). Produção e partição de biomassa, aspectos nutricionais e hídricos em plantios clonais de eucalipto na região litorânea do Espírito Santo (Tese Doutorado em Produção Vegetal, Universidade Estadual do Norte Fluminense, Campos dos Goytacazes, RJ).

Pallardy, S. (2008). Physiology of woody plants (p. 454). San Diego: Academic Press. https://doi.org/10.1016/ B978-012088765-1.50011-7

Péllico, N. S., \& Brena D. A. (1997). Inventário florestal (p. 315). Santa Maria: FSM/CEPEF/FATEC.

Pereira, A. R. (1984). Concentração e distribuição de nutrientes em Eucalyptus grandis em função da idade, cultivado na região do cerrado. Brasil Florestal, 59, 27-37.

Pessotti, J. E. S. (2006). Classificação de Solos das Fazendas da empresa Stora Enso. Relatório Técnico (Dados não Publicados).

Poggiani, F., \& Schumacher, M. V. (2004). Nutrient cycling in native forest. In J. L. M. Gonçalves, \& V. Benedetti (Eds.), Forest nutrition and fertilization (pp. 285-305). Piracicaba: IPEF.

Poggiani, F., \& Schumacher, M. V. (1993). Exportação de biomassa e nutrientes através da exploração dos troncos e das copas de um povoamento de Eucalyptus saligna. IPEF, 25, 37-39.

Ryan, M. G. (2010). Factors controlling Eucalyptus productivity: How water availability and stand structure alter production and carbon allocation. Forest Ecology and Management, 259(9), 1695-1703. https://doi.org/ 10.1016/j.foreco.2010.01.013

SBCS-CQFS (Sociedade Brasileira de Ciência do Solo-Comissão de Química e Fertilidade do Solo-RS/SC). (2016). Manual de calagem e adubação para os Estados do Rio Grande do Sul e de Santa Catarina (11th ed., p. 376). Solo-Núcleo Regional Sul, Porto Alegre

Schumacher, M. V. (1998). Estudo da biomassa e dos nutrientes de um povoamento de Eucalyptus globulus (Labillardière) sub-espécie bicostata. Revista Árvore, 22(2), 281-286.

Schumacher, M. V. (2013). Biomassa e nutrientes no corte raso de um povoamento de Pinus taeda L. de 27 anos de idade em Cambará do Sul-RS. Ciência Florestal, 23(2), 321-332. https://doi.org/10.5902/ 198050989278

Schumacher, M. V., \& Caldeira, M. V. W. (2001). Estimativa da biomassa e do conteúdo de nutrientes de um povoamento de Eucalyptus globulus (labillardière) sub-espécie maidenii. Ciência Florestal, 11(1), 45-53. https://doi.org/10.5902/19805098494

Schumacher, M. V., Witschoreck, R., \& Calil, F. N. (2011). Biomassa em povoamentos de Eucalyptus spp. de pequenas propriedades rurais em Vera Cruz, RS. Ciência Florestal, 21(1), 17-22. https://doi.org/10.5902/ 198050982743

Spangenberg, A. (1996). Nutrient store and export rates of Eucalyptus urograndis plantations in eastern Amazonia (Jari). Forest Ecology and Management, 80, 225-234. https://doi.org/10.1016/0378-1127 (95)03615-6

Streck, E. V. (2008). Solos do Rio Grande do Sul (p. 107). Porto Alegre: UFRGS, EMATER/RS.

Tedesco, M. J., Gianello, C. Bissani, C. A., Bohnen, H., \& Volkweiss, S. J. (1995). Análise de solo, plantas e outros materiais (Boletim Técnico, 5, 2nd ed., p. 174). Porto Alegre: Departamento de Solos, UFRGS.

Turner, J., \& Lambert, M. J. (2008). Nutrient cycling in age sequences of two Eucalyptus plantation species. Forest Ecology and Management, 255, 1701-1712. https://doi.org/10.1016/j.foreco.2007.11.038

Viera, M. (2012). Dinâmica nutricional em um povoamento híbrido de Eucalyptus urophylla $\times$ Eucalyptus globulus em Eldorado do Sul-RS, Brasil (Tese Doutorado em Engenharia Florestal, Universidade Federal de Santa Maria, Santa Maria). https://doi.org/10.4322/floram.2013.021 
Viera, M. (2013). Biomassa e nutrientes em um povoamento de Eucalyptus urophylla $\times$ Eucalyptus globulus em Eldorado do Sul-RS, Brasil. Ecologia e Nutrição de Florestal, 1, 1-13.

Viera, M., Schumacher, M. V., \& Caldeira, M. V. W. (2015). Biomassa e exportação de nutrientes pela colheita florestal. In M. V. Schumacher, \& M. Viera (Eds.), Silvicultura do Eucalipto no Brasil (pp. 245-272). Santa Maria, Editora UFSM.

\section{Copyrights}

Copyright for this article is retained by the author(s), with first publication rights granted to the journal.

This is an open-access article distributed under the terms and conditions of the Creative Commons Attribution license (http://creativecommons.org/licenses/by/4.0/). 